\title{
Effects of an Intercultural Communication Course in Developing Intercultural Sensitivity
}

\author{
İbrahim Tuncel ${ }^{1} \&$ Turan Paker $^{2}$ \\ ${ }^{1}$ Department of Curriculum and Instruction, Faculty of Education, Pamukkale University, Denizli, Turkey \\ ${ }^{2}$ Department of Foreign Language Education, Faculty of Education, Pamukkale University, Denizli, Turkey \\ Correspondence: Turan Paker, Pamukkale Universitesi, Egitim Fakultesi, Oda No: A0310, Denizli 20070 Denizli, \\ Turkey. Tel: 90-535-929-1923. E-mail: tpaker@gmail.com
}

Received: November 12, 2018

Accepted: December 15, 2018

Online Published: December 21, 2018

doi:10.5430/ijhe.v7n6p198

URL: https://doi.org/10.5430/ijhe.v7n6p198

\begin{abstract}
The purpose of the study is to see whether intercultural communication, an elective course, taught through case analyses in the department of English language teaching is effective on the level of students' intercultural sensitivity. For this purpose, we conducted the study based on the explanatory sequential design. The participants were senior students (teacher candidates) in English Language teaching department in Pamukkale University in Turkey. The participants were in two elective courses: intercultural communication and sociolinguistics. The data were collected through intercultural sensitivity scale quantitatively and group focused interviews with students and instructors qualitatively. The quantitative data were analyzed by means of ANOVA for mixed measures to compare the means of two groups. In addition, qualitative data were analyzed through content analysis in terms of emerging codes and themes. Our results indicated that the contribution of intercultural communication course to the development of intercultural sensitivity among students was significant. Both the students and the instructor revealed in the interviews that the activities carried out throughout the semester contributed a lot to increase their awareness towards intercultural communication components and to the development of their intercultural sensitivity.
\end{abstract}

Keywords: intercultural communication, intercultural sensitivity, pre-service English teachers, sociolinguistics

\section{Introduction}

Language is one of the most important components of a culture. As language and culture have inextricable connection in a society, culture should not be ignored in second or foreign language teaching. According to $\operatorname{Er}$ (2006), language is a tool reflecting the way of thinking in a society. As language develops within a culture, thinking in the target language will be possible by being exposed to target language culture. Researchers who attempt to develop language teaching methods and approaches aim at improving the level of intercultural communication competency among learners through various activities and tasks more and more. Thus, first, they have the learners understand the target language culture and create awareness, and then, the learners may develop the intercultural communication competency (Gökmen, 2005).

First of all, we believe that it is important to see the relationship among "intercultural communication," "intercultural competency," "intercultural sensitivity" in order to explicate the conceptual framework of this research. Factors such as commerce, war, immigration, technology, etc. led to the interaction of different cultures throughout the history, and such an interaction has become more complex and unavoidable by the time. Intercultural communication, in fact, defines the process, which results from the exposition and interaction of various cultures with each other, and today, this process is gaining importance day by day. In 1950s, Edward T. Hall did not only introduce the concept of intercultural communication in literature, but contributed to it significantly as a field of study and an academic discipline by explicating the conceptual and theoretical framework of intercultural communication (Roth, 2004).

Individual and cultural factors affect the process of communication. In this process, we can talk about intercultural communication when cultural identity has a leading role and dominant effect on it. Intercultural communication is a process, which takes place between the individuals having different cultural identities (Kartar1, 2001). According to Sar1 (2004), in the process of communication, we can handle with each case in which any cultural difference or differences, or interaction between the differences as intercultural communication.

Intercultural communication competence is composed of the interaction among language competence, sociolinguistic 
competence, discourse competence and intercultural competence (Byram, Gribkova \& Starkey, 2002). According to Matoba \& Scheible (2007), intercultural competence is a tool for intercultural communication. Intercultural competences are construed in terms of knowledge, skill and emotional aspects. Knowledge aspect includes the competences such as getting to know one's own cultural identity and construing one's own cultural awareness, getting to know different cultures, finding out different cultural features, finding out the similar features of different cultures. Skill aspect includes the competences such as listening, observation, analysis, evaluation, adaptation, being flexible, being able to communicate appropriately and effectively, and behaving appropriately depending on the intercultural context. On the other hand, emotional aspect includes the competences such as respecting the differences, clarity, interest and exploration (Auernheimer, 2010; Byram, Gribkova \& Starkey, 2002; Deardorff, 2006). In addition, Chen \& Starosta (1996) called emotional process as intercultural sensitivity; cognitive process as intercultural awareness; and behavioral process as intercultural adroitness in gaining intercultural communication competence.

This study is limited to intercultural sensitivity, which is the emotional aspect of intercultural communication. Intercultural sensitivity is a competence to develop positive emotion encouraging appropriate and effective behavior in terms of intercultural communication in understanding cultural differences. Intercultural sensitivity defines the demand and tendencies in order to understand and accept cultural differences which will result in positive outcome as a result of intercultural communication. The individuals having such sensitivity may have the characteristics such as self-esteem, self-control, open-minded, empathy, interactive relation and not being prejudiced or biased towards others (Chen 1997).

The Higher Education Council (2011, p.6) has identified the national qualifications framework for higher education in Turkey during the preparation of Bologna process. Among the qualifications, there are the competences such as "knowing national and international cultures" in terms of knowledge, "living in different cultures and adapting into social life" in terms of communication and social competence. In addition, one of the vocational qualifications identified by Ministry of Education is "individual and professional values-professional development." This qualification has been described as follows; "teacher does his/her best by taking into students' social and cultural differences, interest and behaviors so that students will learn the topics and improve themselves at the highest level." In addition, in this qualification, under the competence titled, "giving importance to national and universal values, the description has been made as follows; 'teacher adopting children rights, human rights, constitution and democracy principles should be able to arrange teaching contexts within the understanding that each society has their own culture and values" (Ministry of National Education [MEB], 2008, p. 10). These descriptions and performance indicators match with the features needed by the individuals who have intercultural competences. In this context, we can point out that teachers are expected to have the competences related to intercultural communication and intercultural sensitivity among the goals of teacher education programs in Turkey. As teachers, in all fields of study, may have the probability of coming across students with different cultural features, they are expected to have intercultural communication competence. On the other hand, foreign/second language teachers need to have this competence in order to communicate effectively in the target language. However, we have found out that the studies related to intercultural sensitivity in the field of foreign language teaching is limited in Turkey (Baykara, 2010; Harmandaoğlu, 2013; Özdemir, 2004; Yücel, 2016). In other fields of teaching, there are sufficient amount of research related to intercultural sensitivity (Bekiroğlu \& Balcı, 2014; Bektaş, 2006; Bulduk, Tosun \& Ardıç, 2011; Kağnıc1, 2014; Karaırmak, 2008; Rengi \& Polat, 2014; Tertemiz \& Aslantaş, 2016; Üstün, 2011).

The fact that the teacher candidates of English Language Teaching should have intercultural communication competence can be regarded as one of the main qualifications. We have attempted to explain above that the dimensions of such competence are comprehensive. We believe that such studies are necessary in order to find out whether students can gain intercultural communication competence or intercultural sensitivity through a course in their curriculum. We also believe that our study can contribute to English language teachers and teaching in order to create awareness on intercultural communication competence and intercultural sensitivity in their own communication and teaching contexts. Having this purpose in mind, we have focused on two courses 'Intercultural Communication and Sociolinguistics' aiming at creating awareness in cultural aspects of teaching foreign languages and issues in intercultural communication in the ELT curriculum. We believe that such courses may lead learners to be aware of cultural aspects of foreign languages in terms of intercultural communication when their contents were considered.

We believe that some activities and tasks in the intercultural communication course may lead some awareness among students regarding the issues such as respecting the values of people from different cultures, being open minded towards them, getting as much information as possible about other cultures, accepting the ideas of people from 
different cultures, getting rid of prejudice, approaching positively towards fellows with different cultures, being friendly, self-confident, and conducting them with propriety while communicating, and so on.

\subsection{The Purpose of the Study}

The purpose of the study is to identify the possible effects of an Intercultural communication course in developing intercultural sensitivity among candidate teachers and find out the factors, which affect the development of intercultural sensitivity. For this purpose, we have chosen two groups of students who study two elective courses in English Language Teaching curriculum, Namely, these courses are Intercultural Communication and Sociolinguistics. We believe that these courses could contribute to intercultural sensitivity more in terms of their contents. We believe that the results of the research will contribute to design and development of syllabi for intercultural sensitivity. For this purpose, we have the following research questions:

- 1. Is the intercultural communication course effective in developing intercultural communication and intercultural sensitivity?

- 2. What are the reflections of students and instructors on intercultural communication and intercultural sensitivity?

- 3. Is there a statistically significant difference between the mean scores of students studying intercultural communication course before and after taking the course?

- 4. Is there a statistically significant difference between the mean scores of students studying intercultural communication course and those studying sociolinguistics course?

\section{Method}

\subsection{The Design of the Study}

This is a descriptive study to identify the possible effects of an Intercultural communication course in developing intercultural sensitivity. The design of the study is based on the explanatory sequential design, one of the mixed method designs. The objective of this design is to begin the research with quantitative data and continue with qualitative data to explain the quantitative results (Creswell, 2003). This research design helps us triangulate the data, make use of strengths of two types of data to be able to get some facts and understand the sense of process (Cresswell \& Clark, 2011). First of all, quantitative data were gathered through "intercultural sensitivity scale in terms of pre- and post-test where the participants were assigned through convenient sampling. The participants studying the intercultural communication course and those studying the sociolinguistics course were given pre- and post-tests in order to assess whether there is a significant difference within and between the groups. In the second phase of the study, the qualitative data were collected in order to get more data in detail regarding the reflections of the participants and for the purpose of triangulation. For this purpose, the qualitative data were gathered through focused group or individual semi-structured interviews in order to get reflections of the participants on the whole process of studying the intercultural communication course.

\subsection{The Participants}

The participants, candidate teachers, were two groups of students in their 8th semester, in the English Language Teaching Department of Faculty of Education in a state university in Turkey. The students were in two groups: those (40 participants, $65 \%$ of them were female and 35\% were male) who studied the 2 hour elective course titled "intercultural communication" and the others (32 participants, $81.3 \%$ were female and $18.8 \%$ were male) who studied the 2 hour elective course titled "sociolinguistics." All students have taken the same courses in the curriculum including the ones in the $8^{\text {th }}$ semester, except the elective ones. The curriculum of English language teaching department is composed of three types of courses, four language skills (listening, speaking, reading and writing), courses related to teaching English (methodology), and culture courses (literature, history, Turkish culture, etc.).

For the qualitative data collection, by means of maximum variation sampling technique, focused groups were formed as three groups, composed of 5 participants each among the students who take the intercultural communication course. When forming the groups, such variables as gender, the longest dwelling place, and the context whether students' dwelling was in a multicultural environment or not were taken into consideration. 
Table 1. The distribution of socio-demographic features of participants in the study

\begin{tabular}{llllllll}
\hline Variables & Category & $\begin{array}{l}\text { Those taking } \\
\text { intercultural } \\
\text { communication } \\
\text { course }\end{array}$ & $\begin{array}{l}\text { Those taking } \\
\text { socio-linguistics } \\
\text { course }\end{array}$ & Total & & \\
\cline { 2 - 8 } & & $f$ & $\%$ & $f$ & $\%$ & $\mathrm{f}$ & $\%$ \\
\hline \multirow{2}{*}{ Gender } & Female & 26 & 65.0 & 26 & 81.3 & 52 & 72.2 \\
& Male & 14 & 35.0 & 6 & 18.8 & 20 & 27.8 \\
I live in a & City & 18 & 45.0 & 11 & 34.4 & 29 & 40.3 \\
& Town & 21 & 52.5 & 19 & 59.4 & 40 & 55.6 \\
I live in a & Abroad & 1 & 2.5 & 2 & 6.3 & 3 & 4.2 \\
multicultural & Yes & 16 & 40.0 & 4 & 12.5 & 20 & 27.8 \\
environment & No & 24 & 60.0 & 28 & 87.5 & 52 & 72.2 \\
$\begin{array}{l}\text { I have lived in a } \\
\text { multicultural context }\end{array}$ & Yes & 32 & 80.0 & 20 & 62.5 & 52 & 72.2 \\
& No & 8 & 20.0 & 12 & 37.5 & 20 & 27.8 \\
\hline
\end{tabular}

As seen in Table 1, The participants in both groups have similar distribution ratio when they are compared in terms of their socio-demographic features. Majority of the participants have lived in a town (55.6\%), some of them have lived in a city (40.3\%) and very few of them have lived abroad. In addition, $72.2 \%$ of them has not been in a multicultural environment, but only $27.8 \%$ has been in a multicultural environment. Furthermore, they have stated in the questionnaire that they have have lived in a multicultural context for various reasons such as education, travel, tourism and so on.

\subsection{Contents of the Courses}

The intercultural communication course was taught 2 hours per week throughout the $8^{\text {th }}$ semester through case analyses, presentations pair, group or class discussions, and anecdotes and experiences of students who took part in the Erasmus students' exchange program by comparing and contrasting local and target language culture, and focusing on the similarities and differences and intercultural communication problems, experienced culture shocks, etc., and thus, students were aware of communication problems, which may lead to develop intercultural sensitivity. In order to compare and contrast the data in terms of intercultural sensitivity development, the students taking the sociolinguistics course were selected particularly because the course objectives cover that students will gain insights into the relevant social theories regarding the relationship among language, culture and thought or vice versa. As there is a strong tie between language and society, language use might differ from one group of people to another, and these differences might derive from such aspects as social status, region, gender, age, educational background, etc. The contents of the course are related to social and functional use of English with various individuals using different registers in various contexts as English is considered as a lingua franca. Next, both groups focus on language, culture, communication and social relationships in their contents. In addition, the sociolinguistics course was taught 2 hours per week throughout the $8^{\text {th }}$ semester through lectures and discussions.

\subsection{Data Collection Tool}

For quantitative data collection, Intercultural Sensitivity Scale (ISS), developed by Chen and Starosta (2000) and translated and adapted into Turkish by Bulduk, Tosun ve Ardiç (2011), was used as an instrument. After the scale was translated and adapted into Turkish, its Cronbach's Alpha was calculated as .72. In our study, the Cronbach's Alpha was calculated as .83. The original scale is composed of 5 components. When validity of the scale was calculated after translation and adaptation into Turkish culture, the distribution of values of the items in the components did not match with the ones in the original scale. When adapting the scale, the Turkish scholars contacted with Chen, and he approved that the scale could be used as only one component (Üstün, 2011). In this study, we used this approved scale which is based on one component, i.e. intercultural sensitivity. In the scale, there are 24 items, and participants ticked the appropriate choice on the 5 Likert type scale. The choices were ranged from 1 to 5 representing: $1=\mathrm{I}$ strongly disagree, $2=\mathrm{I}$ disagree, $3=\mathrm{I}$ partly agree, $4=\mathrm{I}$ agree, $5=\mathrm{I}$ strongly agree.

For the qualitative data collection, as a result of literature review, the researchers prepared a semi-structured 
interview form at first. In order to provide reliability and validity of the data collection tool, we asked the opinions of other researchers in the field regarding the form. After getting their reflections, the form was revised. Later on, the form was piloted with 3 students and the final form was decided. The semi-structured interview form had some questions in order to get detailed opinions and reflections of students on the learning outcomes of the interlanguage communication course in terms of cognitive and emotional dimensions, the contents of the course, the activities, presentations, film analyses, case analyses and discussions carried out during the course. In addition, some extension questions were posed to be able get in-depth reflections. Furthermore, based on the students' interview form, instructors' interview form was prepared and used.

\subsection{Data Collection Procedure}

First of all, in order to collect quantitative data, pre-test was administered to both groups in the first week of the semester, then, post-test was administered to both groups in the fourteenth week of the semester by means of the Intercultural Sensitivity Scale. Furthermore, qualitative data were collected through focused group interviews with students and individual interview with the instructor.

\subsection{Data Analysis}

First of all, in order to have the normality analysis of our quantitative data, we have carried out the Shapiro-Wilk test because it is the most appropriate test when the group size is less than 50 (Büyüköztürk, 2009), and we have found out that our data has normal distribution. In addition, we have calculated and interpreted our data through two-way ANOVA for mixed measured in order to compare pretest-posttest results of the intercultural communication group, and the results of both groups, and for other measurement purposes. When interpreting means of the groups for the intercultural sensitivity perception, arithmetic means were interpreted according to the values as follows: the lowest score to be obtained from the scale is 24 points while the highest is 120 points. On the other hand, we have analyzed our qualitative data gathered through focused group interview with students and the instructors through content analysis. First, the data were coded and the themes extracted out of codes were constructed.

\section{Results}

The descriptive statistical results of the students regarding their level of perception for intercultural communication sensitivity were presented in Table 2 .

Table 2. The students' level of perception for intercultural communication sensitivity

\begin{tabular}{|c|c|c|c|c|c|c|c|}
\hline \multirow{2}{*}{ Group } & \multirow{2}{*}{$\mathrm{n}$} & \multicolumn{2}{|c|}{ Mean of items } & \multicolumn{2}{|l|}{$\bar{x}$} & \multicolumn{2}{|c|}{$\begin{array}{l}\text { Std. } \\
\text { Deviation }\end{array}$} \\
\hline & & Pre & Post & Pre & Post & Pre & Post \\
\hline Intercultural Com. & 40 & 3.85 & 4.14 & 92.52 & 99.35 & 9.50 & 9.26 \\
\hline Sociolinguistics & 32 & 3.77 & 3.84 & 90.50 & 92.31 & 9.77 & 8.41 \\
\hline Total & 72 & 3.81 & 4.00 & 91.62 & 96.22 & 9.61 & 9.50 \\
\hline
\end{tabular}

When we analyze Table 2, we have found out that the mean score of the intercultural communication group is $\bar{x}=92.52$, while the mean score of the sociolinguistics group is $\bar{x}=90.50$ for the pre-test. We can point out that the students having higher intercultural sensitivity tend to choose the elective course intercultural communication. In addition, the English Language Teaching students in both groups (intercultural communication and sociolinguistics) have shown that they have high intercultural sensitivity in both pre $(\bar{x}=91.62)$ and post $(\bar{x}=96.22)$ tests. Hence, we can state that either their experiences or the courses in their curriculum have helped them develop intercultural sensitivity to some extent.

Table 3. Pre-test results of the students in intercultural communication and sociolinguistics groups obtained from the intercultural sensitivity scale.

\begin{tabular}{lllllll}
\hline & $\mathrm{n}$ & $\bar{x}$ & Std. Deviation & $\mathrm{df}$ & $\mathrm{t}$ & $p$ \\
\hline Intercultural Com. & 40 & 92.52 & 9.50 & 70 & .887 & .378 \\
Sociolinguistics & 32 & 90.50 & 9.77 & & &
\end{tabular}

$$
p>.05
$$


There is no statistically significant difference between intercultural communication and sociolinguistics groups for the pre-test according to the t-test result $\mathrm{t}(70)=.887, p>.05$ (Table 3). This result shows that the level of intercultural sensitivity for both groups of students are similar.

On the other hand, two-way ANOVA results were presented in Table 4 in order to show whether there is a statistically significant difference between and within the groups for the pretest-posttest.

Table 4. Pretest-posttest ANOVA results of the students in intercultural communication and sociolinguistics groups obtained from the intercultural sensitivity scale.

\begin{tabular}{|c|c|c|c|c|c|c|}
\hline Variances Source & Sum of Squares & $\mathrm{df}$ & $\begin{array}{l}\text { Mean } \\
\text { Square }\end{array}$ & $F$ & $p$ & $\begin{array}{l}\text { Partial Eta } \\
\text { Squared }\end{array}$ \\
\hline Between the groups & 10212.66 & 71 & & & & \\
\hline $\begin{array}{l}\text { Groups (Intercultural } \\
\text { Com/Sociolinguisitcs) }\end{array}$ & 730.035 & 1 & 730.035 & 5.38 & $.023 *$ & .071 \\
\hline Error & 9482.625 & 70 & 135.466 & & & \\
\hline Within the groups & 3429.828 & 72 & & & & \\
\hline (Pretest-Posttest) & 663.168 & 1 & 663.168 & 18.252 & $.000 *$ & .207 \\
\hline Group*Calculation & 223.335 & 1 & 223.335 & 6.147 & $.016^{*}$ & .081 \\
\hline Error & 2543.325 & 70 & 36.333 & & & \\
\hline Total & 13642.488 & 143 & & & & \\
\hline
\end{tabular}

When we analyze Table 4, we can state that there is a statistically significant difference between the students studying the intercultural communication course and those studying the sociolinguistics course in terms of the level of intercultural sensitivity $(\mathrm{F}(1,70)=6.14, \mathrm{p}<.05)$. This finding indicates that the courses intercultural communication and sociolinguistics have different effects in developing the intercultural sensitivity level of the students. Thus, we have found out that the intercultural communication course was more effective in developing the intercultural sensitivity level of the students compared to the sociolinguistics (Table 4).

When students' opinions were analyzed according to the items in the scale, we have the following results: The range of the means of the items in terms of level of praticipation is as follows: $1.00-1.80$ Strongly Disagree, 1.81 2.61 Disagree, 2.62 - 3.42 Partly Agree, 3.43-4.23 Agree, 4.24-5.00 Strongly Agree 
Table 5. The items whose mean scores changed in the pretest-posttest results in the intercultural communication group.

\begin{tabular}{|c|c|c|}
\hline $\begin{array}{l}\text { The items whose mean scores changed in } \\
\text { the pretest-posttest }\end{array}$ & $\begin{array}{l}\text { Pre-test } \\
\text { mean scores }\end{array}$ & $\begin{array}{l}\text { Post-test } \\
\text { mean scores }\end{array}$ \\
\hline $\begin{array}{l}\text { 2. I believe that the people in different cultures are narrow minded. } \\
\text { (Reverse Code) }\end{array}$ & $\begin{array}{l}4.15 \\
\text { (Disagree) }\end{array}$ & $\begin{array}{l}4.47 \\
\text { (Strongly Disagree) }\end{array}$ \\
\hline $\begin{array}{l}\text { 5. I usually know what to say when I communicate with the people } \\
\text { from different cultures. }\end{array}$ & $\begin{array}{l}3.22 \\
\text { (Partly Agree) }\end{array}$ & $\begin{array}{l}3.62 \\
\text { (Agree) }\end{array}$ \\
\hline 8. I respect the values of people from different cultures. & $\begin{array}{l}4.20 \\
(\text { Agree })\end{array}$ & $\begin{array}{l}4.52 \\
\text { (Strongly Agree) }\end{array}$ \\
\hline 13. I am open minded towards people from different cultures. & $\begin{array}{l}4.10 \\
\text { (Agree) }\end{array}$ & $\begin{array}{l}4.40 \\
\text { (Strongly Agree) }\end{array}$ \\
\hline $\begin{array}{l}\text { 15. I usually feel useless when I communicate with the people from } \\
\text { different cultures. (Reverse Code) }\end{array}$ & $\begin{array}{l}4.10 \\
\text { (Disagree) }\end{array}$ & $\begin{array}{l}4.25 \\
\text { (Strongly Disagree) }\end{array}$ \\
\hline $\begin{array}{l}\text { 17. I try to get as much information as possible when I communicate } \\
\text { with the people from different cultures. }\end{array}$ & $\begin{array}{l}4.00 \\
\text { (Agree) }\end{array}$ & $\begin{array}{l}4.45 \\
\text { (Strongly Agree) }\end{array}$ \\
\hline $\begin{array}{l}\text { 18. I cannot accept the ideas of people from different cultures. } \\
\text { (Reverse Code) }\end{array}$ & $\begin{array}{l}4.22 \\
\text { (Disagree) }\end{array}$ & $\begin{array}{l}4.57 \\
\text { (Strongly Disagree) }\end{array}$ \\
\hline $\begin{array}{l}\text { 20. I think that my culture is better than other cultures. (Reverse } \\
\text { Code) }\end{array}$ & $\begin{array}{l}3.07 \\
\text { (Partly Agree) }\end{array}$ & $\begin{array}{l}3.47 \\
\text { (Disagree) }\end{array}$ \\
\hline $\begin{array}{l}\text { 21. I usually approach positively towards fellows with different } \\
\text { cultures while communicating. }\end{array}$ & $\begin{array}{l}4.02 \\
\text { (Agree) }\end{array}$ & $\begin{array}{l}4.35 \\
\text { (Strongly Agree) }\end{array}$ \\
\hline $\begin{array}{l}\text { 24. I enjoy the differences when the fellows I communicate have } \\
\text { different cultures. }\end{array}$ & $\begin{array}{l}3.75 \\
\text { (Agree) }\end{array}$ & $\begin{array}{l}4.40 \\
\text { (Strongly Agree) }\end{array}$ \\
\hline
\end{tabular}

When we analyze the mean scores of the items in Table 5, we can point out that there is a positive change, which means that there is an increase in the level of intercultural sensitivity among students.

Table 6. The items whose mean scores changed in the pretest-posttest results in the sociolinguistics group

\begin{tabular}{|c|c|c|}
\hline The items whose mean scores changed in the Pretest-posttest & $\begin{array}{l}\text { Pre-test } \\
\text { mean scores }\end{array}$ & $\begin{array}{l}\text { Post-test } \\
\text { mean scores }\end{array}$ \\
\hline $\begin{array}{l}\text { 2. I believe that the people in different cultures are narrow minded. } \\
\text { (Reverse Code) }\end{array}$ & $\begin{array}{l}4.06 \\
\text { (Disagree) }\end{array}$ & $\begin{array}{l}4.37 \\
\text { (Strongly Disagree) }\end{array}$ \\
\hline 14. I pay more attention to conduct them with propriety when & 4.15 & 4.31 \\
\hline I communicate with the people from different cultures. & (Agree) & (Strongly Disagree) \\
\hline 16. I respect the behaviours of people from different cultures. & $\begin{array}{l}4.15 \\
(\text { Agree })\end{array}$ & $\begin{array}{l}4.31 \\
\text { (Strongly Agree) }\end{array}$ \\
\hline $\begin{array}{l}\text { 18. I cannot accept the ideas of people from different cultures. } \\
\text { (Reverse Code) }\end{array}$ & $\begin{array}{l}4.03 \\
\text { (Disagree) }\end{array}$ & $\begin{array}{l}4.28 \\
\text { (Strongly Disagree) }\end{array}$ \\
\hline $\begin{array}{l}\text { 22. I will avoid the situations if I have to deal with the people from } \\
\text { different cultures. (Reverse Code) }\end{array}$ & $\begin{array}{l}3.31 \\
\text { (Partly Agree) }\end{array}$ & $\begin{array}{l}3.68 \\
\text { (Disagree) }\end{array}$ \\
\hline
\end{tabular}

According to the mean scores of the items, there is a change only in 5 items positively in the mean scores of the sociolinguistics group, however, there is a change in 10 items positively in the mean scores of the intercultural communication group. Therefore, we can point out that the intercultural communication course has contributed more to the development of intercultural sensitivity of the students compared to the sociolinguistics course. 
Table 7. The items whose mean scores have not changed in the pretest-posttest results in the intercultural communication group.

\begin{tabular}{|c|c|c|}
\hline The items whose mean scores have not changed & $\begin{array}{l}\text { Pre-test } \\
\text { mean scores }\end{array}$ & $\begin{array}{l}\text { Post-test } \\
\text { mean scores }\end{array}$ \\
\hline 1. I enjoy communicating with people with different cultures. & 4.32 & 4.52 \\
\hline $\begin{array}{l}\text { 3. I am quite self-confident when I communicate with the people } \\
\text { from different cultures. }\end{array}$ & 3.47 & 3.75 \\
\hline $\begin{array}{l}\text { 4. I have difficulty communicating with people from different } \\
\text { cultures. (Reverse Code) }\end{array}$ & 3.72 & 4.02 \\
\hline $\begin{array}{l}\text { 6. I am very friendly when I communicate with the people from } \\
\text { different cultures }\end{array}$ & 3.52 & 3.97 \\
\hline $\begin{array}{l}\text { 7. I don't enjoy being together with people from different cultures. } \\
\text { (Reverse Code) }\end{array}$ & 4.30 & 4.45 \\
\hline $\begin{array}{l}\text { 9. I feel nervous easily when I communicate with the people from } \\
\text { different cultures (Reverse Code) }\end{array}$ & 3.50 & 3.85 \\
\hline $\begin{array}{l}\text { 10. I have self-confidence when I communicate with the people from } \\
\text { different cultures. }\end{array}$ & 3.65 & 3.95 \\
\hline $\begin{array}{l}\text { 11. I prefer to wait for a while before I have an opinion about the } \\
\text { fellows from different cultures. }\end{array}$ & 4.07 & 4.17 \\
\hline $\begin{array}{l}\text { 12. I feel discouraged when I communicate with the people from } \\
\text { different cultures. (Reverse Code) }\end{array}$ & 3.90 & 4.22 \\
\hline $\begin{array}{l}\text { 14. I pay more attention to conduct them with propriety when I } \\
\text { communicate with the people from different cultures. }\end{array}$ & 4.32 & 4.32 \\
\hline 16. I respect the behaviours of people from different cultures. & 4.32 & 4.45 \\
\hline $\begin{array}{l}\text { 19. I am sensitive to the implied statements and comments of my } \\
\text { fellows from different cultures during the communication. }\end{array}$ & 3.10 & 3.00 \\
\hline $\begin{array}{l}\text { 22. I will avoid the situations if I have to deal with the people from } \\
\text { different cultures. (Reverse Code) }\end{array}$ & 3.65 & 4.00 \\
\hline $\begin{array}{l}\text { 23. I usually reflect my feelings verbally or nonverbally to my } \\
\text { fellows from different cultures. }\end{array}$ & 3.80 & 4.12 \\
\hline
\end{tabular}

In order to explain the effectiveness of the intercultural communication course on students in detail, we have also made use of qualitative data. Hence, we have analyzed the data gathered from focused interviews with the students and the instructors and come across the following codes and themes (Table 8). In coding the quotations from students, we labelled them as $\mathrm{M}$ for Male, and $\mathrm{F}$ for Female students.

Table 8. Codes and themes extracted from the qualitative data

\begin{tabular}{lll}
\hline THEMES & CODES & Frequency \\
\cline { 2 - 3 } Cognitive & Getting to know different cultures & 8 \\
& $\begin{array}{l}\text { Creating awareness towards their own culture } \\
\text { Being aware of cultural similarities }\end{array}$ & 12 \\
& $\begin{array}{l}\text { Being aware of prejudice against } \\
\text { cultures other }\end{array}$ & 7 \\
& Avoiding prejudice against other cultures & 5 \\
& Being able to have empathy & 6 \\
Eearning to tolerate & 9 \\
Activities to improve & Accepting the differences and varieties & 11 \\
intercultural sensitivity & Case analysis of films or texts & 11 \\
& Collaborative learning & 9 \\
& Simulations & 3 \\
& Sharing experiences & 11 \\
\hline
\end{tabular}




\subsection{Theme: Cognitive}

\subsubsection{Code: Getting to Know Different Cultures}

According to the data gathered from focused group interview, the students have reflected that they have learned a lot from the topics and activities through sharing experiences, film analysis and readings such as verbal and non-verbal communication, greeting types, home styles, fooTd, small talk, culture shock, etc.

"We have learned some information about other cultures through internet research. Yet, I can't say that it is sufficient because time allocation for this course is insufficient to analyze the cultural features of a country. What we know about the culture of a country is based on the films we have watched." (Interview 1M1)

"These activities do not create extensive difference in my mind, they are what everybody knows, there was not much that I did not know about." (Interview 1F 2)

"For example, if I go to France, I have to behave or I have to do in such a way, and things like that that everybody knows. Everyone knows how Japanese people greet each other, we have seen them. In order to have detailed information, the time allocation for this course is insufficient. If I should go to France now, I will have some problems again. We have had some general information about other cultures.” (Interview 1M2)

When we analyze the quotations from the students, we can understand that the students point out the insufficient time for the course, and the information presented was not enough to get to know different cultures in terms of having detailed information related to a culture, understanding different cultures and understanding them appropriately, which are related to cognitive dimension of intercultural sensitivity. The duration of the course hours were indicated as insufficient.

\subsubsection{Code: Creating Awareness towards the Students' Own Culture}

According to the interview data, we understand that students compare and contrast their culture with different cultures while trying to get to know other cultures, and they start to inquire the elements of their own culture. We believe when students compare and contrast their culture with different cultures, they increase their awareness towards their own culture. We can understand such awareness from their quotations:

"In fact, we are not aware of the features of our culture but while analysing a case in terms of culture in the class, we start to compare and contrast it with our own, which creates awareness." (Interview record 3F3)

"I realized that some people give more importance to their culture. We started to be like them more. We have lost some features of our culture while trying to be like Europeans for the sake of modernity in the society. For example, while watching wedding ceremonies I thought about the weddings in my childhood. When I was a child wedding ceremonies used to last five days and each day used to have a different activity. Nowadays, people have a wedding ceremony in a hall even in a village and the ceremony lasts one or two days. I feef that I should have my wedding ceremony as was in my childhood days. ." (Interview record 3F2)

\subsubsection{Code: To Identify Cultural Similarities}

It has been found out that students develop positive emotional tendency when they realize that there are some similarities between their own culture and the other culture compared. During the interviews, they remembered the identified similarities more between the two cultures and they were interested that culture more. In this context, we can point out that when students discover and are aware of cultural similarities, it may have an important effect to develop intercultural sensitivity.

"There were times that we were surprised. There were some cases or situations that we could not help thinking that the people in the other culture and our culture have similar reactions, attitudes, etc. We were aware of cultural similarities... For instance, we found out that there were conservative families as in our society and they had some strict rules to obey, e.g. they have to be altogether as a family for dinner." (Interview Record 2M1).

\subsection{Theme: Emotional}

\subsubsection{Code: Being Aware of Prejudices}

In developing intercultural sensitivity, prejudices can create important obstacles. As a result of interview analyses, it was understood that the students carried out some activities by analyzing some cases through watching films or reading texts and group and class discussions to avoid prejudice or to get rid of their prejudice (if they had) towards different cultures. Some reflections on these issues are as follows: 
"The task asked students to write down both positive and negative as to what they knew about such counties: Mozambique, Sri Lanka, Japan, France, Germany, Russia, etc. I have given some example as to how people have prejudices. Although the students can state some utterances about Germany depending on what they have watched in some films before or the things they have heard from other people, they have no idea or prejudice about Mozambique or Sri Lanka. I believe that this activity was very useful to revise their own prejudices against other cultures." (Interview Record, Instructor).

In the following quotation, a student pointed out that thanks to the activity in the class she was aware of her prejudice.

"In the class, our opinion was asked about Iranians, Americans or Russians and we shared both our positive and negative opinions about them. It is a well-known statement that Turkish people are known to have an idea about all topics. But It was not like that in our class. It was surprising for me that there were some students who stated that they had no idea about Russians or Iranians as they had never met one before... I realized that some students did not have prejudice against them or they did not have any ideas about them. Hence, I can state that my opinion about Turkish people regarding this topic has changed a little. I think my opinion was a prejudice against Turkish people... (Interview Record 3F3).

\subsubsection{Code: Avoiding Prejudices}

During the interview, some students have reported that analyzing various cases, films or written texts, listening to students' experiences, instructor's anecdotes or experiences have helped them to avoid prejudices against different cultures or people.

"In one of the sessions, our instructor asked our opinion about Iranian people and some of our friends stated that they were usually strict and distant people. However, our instructor told about his experience in which he had some problems; although his close friends did not help him, an Iranian guy wanted to help him... This case is surprising and changes belief and attitude of a person (Interview record 2F1)."

"Our instructor has asked us what we think about Chinese people and what we know about them. Most of us told negative things about them. Then, he asked us whether we had met a Chinese person and communicated with him/her. Our answer was no. Thus, he suggested that we should not comment on this matter (Interview record 2F2)."

The cases analyzed in the classes have indicated how prejudices are constructed against other cultures due to lack of knowledge or misinformation. It is clear from students' quotations that the instructor has tried to create awareness towards intercultural sensitivity by suggesting students that they should avoid prejudice against people in different cultures without actually meeting them and that they should behave according to their own experiences.

\subsubsection{Code: Being Able to Empathize}

In the development of intercultural sensitivity, one of the important factors is the ability to empathize. The case analyses in the intercultural communication course have helped students to be able to empathize for others. In the following responses of some students it is emphasized that students have attempted to understand their feelings and emotions by putting themselves into the shoes of the people in different cultures in various cases analyzed in the course. Such analyses may have been effective to develop some intercultural sensitivity among them.

"What we have gained in this course is the ability to compare and contrast different cultures. Perhaps we cannot do it practically, but when we come across the case, we cannot help ourselves to compare and contrast. For example, when we talk about the female circumcision, it was an odd subject to talk about in our culture, however, it was a normal thing for a Somalian or African people. It helped us think that if we had been born in that culture, we would perceive it as a normal procedure in the life of a woman. This case has helped us to be more tolerant towards other cultures. I can point out that we have learned to be more understanding by comparing and contrasting our culture with others (Interview record 3F2)."

"As a matter of fact, most of us are aware that culture is different from one society to the other in the world, and cultures have differences. We have discussed how people in other cultures perceive our culture or how we perceive them in this course, which was very useful (Interview record 2F2)."

\subsubsection{Code: Learning to Tolerate}

One of the important issues in developing intercultural sensitivity is having tolerance towards differences in various cultures. One student points out that the effect of studying different cultures and living with different cultures has an important role in learning to tolerate others. 
"I began to tolerate other cultures as much as I have learned English culture and other cultures in the class. For instance, I was intolerant for being homosexual and similar things before, but by the time, I began to tolerate them. My culture is very different from Fatih.... no need to go to other countries, we are really different from each other, our religion is different. However, we tolerate each other and we do not have any problems... (Interview record 1F1)."

\subsubsection{Code: Accepting the Differences}

Students pointed out that another contribution of this course was accepting the differences. Some students stated that they began to have the opinion that differences in various cultures are natural by studying the other cultures during the course. It indicates that such a course may contribute to the students to develop intercultural sensitivity through various tasks. Some quotations below from students' interviews support this idea:

"I accept that people in different cultures may have different traditions, thinking styles, opinions, belief systems and this is so natural. In my opinion this is the main contribution of the course...(Interview record 2F3)."

"A person cannot choose the place where s/he is born, thus, I believe that if I had been born in a different country, I would have a different culture... I think we should perceive the issue from this perspective (Interview record 2M1)."

"I can state that having experience with different cultures teach us to naturally accept the differences. I don't think students in other departments go through such experience. I believe that we can develop such attitude as we are in the English Language Teaching department (Interview record 2F2)."

\subsection{Theme: Activities Contributing to the Development of Intercultural Sensitivity}

When the quotations extracted from the interviews with the instructor and students were analyzed, it was found out that the intercultural communication course included activities and tasks such as case analyses through films and written texts, discussions on various topics, collaborative learning process through online research, books, magazines or newspapers, simulations, the anecdotes and experiences of the instructor, thought provoking discussions or debates on hot topics, e.g. getting married to a person from non-muslim culture, sharing experiences of students, especially those who studied in the Erasmus students' exchange programs in various European countries. We believe that such activities and tasks have contributed a lot to students to develop intercultural sensitivity. Some quotations of students from interview scripts below support our findings:

"Films are very useful for us. I have asked students to form their own group, each of which was composed of 3 or 4 students. Each group volunteered to present on one of the topics which we had decided on our syllabus such as co-culture, micro-culture, dominant culture, Communication perspectives, Cultural patterns and communication, Self, family and society, Cultural identity, cultural bias, human nature and so on. The group first presents some theoretical framework and then, we watch a related short film or fragments from films, later on we have group and class discussions. Meanwhile, I share my experience with different cultures... we discuss pros and cons. We sometimes have short simulations (Interview record Inst.)."

"We find appropriate films from internet depending on the topic we are going to present, then after or during the presentation we watch altogether and compare and contrast cultures. We sometimes have short texts, we read them and discuss about them. In addition, I enjoyed listening to the experiences of our instructor when he was abroad related to the topic (Interview record 1F1)."

" The most effective thing for me was when our instructor shared his experiences when he was abroad, for example, his accounts beginning with ' once I was invited to dinner in France, or I wanted to borrow some money from my Iranian friend, when I was in the US, or When I went to the Netherlands, etc. They were very attractive and impressive. I believe that sharing his experiences abroad has positively affected my opinion towards different cultures (Interview record 3F1)."

\section{Discussion and Conclusion}

Initially it has been understood that there is no statistically significant difference between the 8th semester students who registered either Intercultural communication or Sociolinguistics courses. However, it has been found out that the intercultural sensitivity level of the students in both groups is high before they take the either course. In this context, we can point out that the courses they have taken in the department or their experiences might have contributed to their intercultural sensitivity level to some extent. On the other hand, at the end of the semester, our data have revealed that there is a statistically significant difference in favor of those who have taken the intercultural communication course according to the posttest means scores obtained from the intercultural sensitivity scale. It 
seems that the intercultural communication course has been more effective in developing intercultural sensitivity of the students. However, it is not fair to see the intercultural communication course as the main cause for the development of intercultural sensitivity of the students because there are various factors affecting their intercultural sensitivity such as the real interaction of students with different cultures, and their experiences when they communicate with people from other cultures. Yet, the effectiveness of the educational programs as in the case of this study should not be ignored.

An important outcome of this research is that the intercultural communication course has developed the intercultural sensitivity of the students to an important degree. An experimental research conducted by Kural (2015) indicated that a course designed and taught for the purpose of developing intercultural skills contributed a lot to the intercultural sensitivity of the students compared to those who did not take such a course. The course covered various activities such as understanding, accepting and respecting different cultures, avoiding prejudice against them, being flexible towards them, getting interested in different cultures, learning to be patient in the case of ambiguity and having motivation to get more knowledge about different cultures. S1k1 (2014) compared students' intercultural sensitivity levels in foreign language education programs in various universities, and concluded that the students in the programs which had courses aiming at developing intercultural sensitivity had higher sensitivity level than those attending to the programs which did not have any courses as such. In addition, Yücel (2016) found out that in the study with the teacher candidates in the ELT department, intercultural education course played a significant role in acquiring the importance of intercultural education and increasing the awareness of the participants. In order to clarify the quantitative results of this study indicating that the intercultural communication course was effective and to give more details regarding the course procedures, qualitative data have been used. As a result of the analysis of the qualitative data, we found out 12 codes, and out of these codes, we reached three themes which cover cognitive, emotional and sensitivity developing activities. The results indicated that the knowledge learned in the intercultural communication course was not limited to get to know different cultures in detail. The duration of the course was insufficient in order to get to know different cultures comprehensively, however, the activities in the course contributed to the students to investigate and evaluate their own cultural knowledge and skills and they had positive effect in developing intercultural sensitivity of the students.

In the course of intercultural communication, students had activities to analyze different cultures through cases and compare/contrast them. Such a learning process has increased the students' awareness towards their own culture and, in addition, helped them discover cultural similarities between their own and the other cultures. Chen (1997) emphasized that the educational programs which promote intercultural sensitivity should encourage and contribute to the understanding of cultural differences and similarities. Due to the geographical position of Turkey, there are a lot of immigrants in the country and in the classrooms of the schools naturally. In this context, teachers need to be sensitive for the intercultural communication as well as intercultural issues. In the case of English language teachers, having intercultural sensitivity for the other culture will help them teach the foreign language effectively and create more windows to look at the world from different perspectives.

Our data indicated that the case analysis and simulation activities during the course contributed to the emotional dimension of intercultural competence, which included identifying prejudices and avoiding them, having empathy, tolerance and accepting differences. In addition, the case analyses, collaborative learning tasks, simulations, sharing intercultural experiences of students, and particularly the experiences of the instructor contributed a lot to intercultural sensitivity of the students. According to Senemoğlu (2012), collaborative learning improves the interaction of students from different cultures, and helps them have tolerance, empathy and contributes to living in a democratic life style.

The results of this study has indicated that the contribution of intercultural communication course to the development of intercultural sensitivity among students is significant. The intercultural communication course is an elective course in the curriculum of English language teaching department. Such a course may be a compulsory course in all departments to create awareness and hopefully to develop intercultural sensitivity among all teacher candidates in all departments.

Although in this specific study, only one course has been effective to contribute to the development of intercultural sensitivity among students, it should be taken into account that the time allocation for such a course would not be sufficient to have the students gain intercultural communication competence, which has multi-dimensional aspects and eventually to develop intercultural sensitivity. Hence, it is necessary to design educational programs that have interdisciplinary approach aiming to have students gain intercultural communication competence and intercultural sensitivity. 
We suggest that some other research designs may be conducted in the English Language Teaching programs in order to identify the role of other courses in the development of intercultural sensitivity. An experimental research design may be carried out to find out the effects of intercultural communication course compared to other similar courses.

In this research design, the intercultural sensitivity scale, one of the instruments to collect data, is limited to measure the intercultural sensitivity, which is one of the components of intercultural communication. Therefore, the results of the study should be considered solely in terms of creating awareness and the development of intercultural sensitivity.

\section{References}

Auernheimer, G. (2010). Interkulturelle kommunikation, mehrdimensional betrachtet, mit konsequenzen für das verständnis interkultureller kompetenz. In G. Auernheimer (Hg.), Interkulturelle kompetenz und pädagogische professionalität (pp. 35-65). Wiesbaden: VS Verlag für Sozialwissenschaften. https://doi.org/10.1007/978-3-531-92312-3_3

Baykara B. (2010). Yabancl dil eğitiminde kültürlerarasıllk. [Interculturalism in foreign language education] (Yayımlanmamış yüksek lisans tezi) [Unpublished master's thesis]. Fırat Üniversitesi Sosyal Bilimler Enstitüsü, Elazığ.

Bekiroğlu, O. \& Balcı, Ş. (2014). Kültürlerarası iletişim duyarlılığının izlerini aramak: İletişim fakültesi öğrencileri örneğinde bir araştırma. Selçuk Üniversitesi Türkiyat Araştırmaları Dergisi, 35,429 - 459. https://doi.org/10.21563/sutad.187110

Bektaş, Y. (2006). Kültüre duyarlı psikolojik danışma yeterlikleri ve psikolojik danışman eğitimindeki yeri. [Multicultural Counseling Competences and The Place of Multicultural Competences in Counseling Education] Ege Eğitim Dergisi, 7(1), 43-59.

Bulduk, S., Tosun, H. \& Ardıç, E. (2011). Türkçe kültürler arası duyarlılık ölçeğinin hemşirelik öğrencilerinde ölçümsel özellikleri [Measurement properties of Turkish intercultural sensitivity scale among nursing students]. Turkiye Klinikleri J Med Ethics, 19(1), 25-31.

Büyüköztürk, Ş. (2009). Sosyal bilimler için veri analizi el kitabı: İstatistik, araştırma deseni Spss uygulamaları ve yorum. Ankara: Pegem Yayıncılık

Byram, M., Gribkova, B., \& Starkey, H. (2002). Developing the intercultural dimension in language teaching: A practical introduction for teachers. The Council of Europe. Retrieved April, 24, 2016 from http://lrc.cornell.edu/director/intercultural.pdf

Chen, G. M., \& Starosta, W. J. (1996). Intercultural communication competence: A synthesis. Communication Yearbook, 19, 353-384.

Chen, G - M (1997, January). A Review of the concept of intercultural sensitivity. Paper presented at the biennial convention of Pacific and Asian Communication Association, Honolulu, Hawaii.

Chen, G - M., \& Starosta, W. J. (2000, November). The development and validation of the intercultural sensitivity scale. Paper presented at the Annual Meeting of the National Communication Association, Seattle, WA.

Creswell, J. W. (2003). Research design: Qualitative, quantitative, and mixed methods approaches (2nd ed.). Thousand Oaks, CA: Sage.

Cresswell, J.W. \& Clark, V.L.P. (2011). Designing and conducting mixed methods research (2nd ed.). London: Sage.

Deardorff, D. K. (2006). Identification and assessment of intercultural competence as a student outcome of internationalization. Journal of Studies in Intercultural Education, 10(3), 241-266. https://doi.org/10.1177/1028315306287002

Er, K. O. (2006). The Effects of Culture in Foreign Language Curriculum. Ankara University Journal of Faculty of Educational Sciences. 39 (1), 1-14.

Gökmen, M. E. (2005). Yabancı dil öğretiminde kültürlerarası iletişimsel edinç. Dil Dergisi, 128, 69-78 https://doi.org/10.1501/Dilder_0000000035

Harmandaoğlu, E. (2013). Promotıng intercultural competence of teacher trainees in english language departments via web 2.0 tools: a case study. [Unpublished master's thesis]. Gazı University The Institute of Educational Sciences, Ankara.

Kagnici, D. Y. (2014). Reflections of a Multicultural Counseling Course: A Qualitative Study with Counseling Students and Counselors. Educational Sciences: Theory and Practice, 14(1), 53-62. 
https://doi.org/10.12738/estp.2014.1.1965

Karaırmak, Ö. (2008). Çok kültürlülük, kültürel duyarlılık ve psikolojik danışma. Türk Psikolojik Danısma ve Rehberlik Dergisi, 3(29), 115-129.

Kartarı, A. (2001). Farklllıklarla yaşamak kültürlerarası iletişsim. Ankara: Ürün Yayınları

Kural, F. (2015). Significance of intercultural competence development for study-abroad students: preparing Turkish international sojourners to undertake graduate programs in English L1 countries (Unpublished doctoral dissertation). Yeditepe Üniversity Institute of Educational Sciences, İstanbul.

Matoba, K., \& Scheible, D. (2007). Interkulturelle und transkulturelle kommunikation. Working Paper of International Society for Diversity Management e. V. 3.

Retrieved from http://www.idm-diversity.org/files/Working_paper3-Matoba-Scheible.pdf.

Ministry of National Education $\square$ Milli Eğitim Bakanlığı (MEB) $\square$. (2008). Öğretmen yeterlikleri öğretmenlik mesleği genel ve özel alan yeterlikleri. Ankara: Devlet Kitapları Müdürlüğ̈̈

Özdemir, E. (2004). Attitudes of Turkish pre-service english language teachers towards other cultures in intercultural communication context (Unpublished master's thesis). İstanbul Üniversitesi Sosyal Bilimler Enstitüsü, İstanbul.

Rengi, Ö. \& Polat, S. (2014). Sınıf öğretmenlerinin kültürel farklılık algıları ve kültürlerarası duyarlılıkları [Primary teachers' perception of cultural diversity and intercultural sensitivity]. Zeitschrift für die Welt der Türken, 6(3), $135-156$

Roth, K. (2004) Kulturwissenschaften und Interkulturelle Kommunikation. Der Beitrag der Volkskunde zur Untersuchung interkultureller Interaktionen. In Hans-Jürgen Lüsebrink (Hrsg.), Konzepte der interkulturellen Kommunikation. Theorieansätze und Praxisbezüge in interdisziplinärer perspektive (pp. 115-143). St. Ingbert: Röhrig Universitätsverlag.

Sarı, E. (2004). Kültürlerarası iletişim: Temeller, gelişmeler, yaklaşımlar. Folklor/Edebiyat, 3(39), 1-31.

Senemoğlu, N. (2013). Gelişim, ögrenme ve ögretim. Kuramdan uygulamaya. Ankara: Yargı Yayınevi

Sık1, E. (2014). Yabanci dil ögretiminde kültür farkindaliği yaratma ve kültürlerarasi iletişim becerilerinin gelişstirilmesi (Unpublished master's thesis). Marmara Üniversitesi Sosyal Bilimler Enstitüsü, İstanbul.

Tertemiz, N. \& Aslantaş, S. (2016). Çokkültürlü eğitime dayalı proje çalışmasının sınıf öğretmeni adaylarının kültürlerarası duyarlılık düzeylerine etkisi. Ufuk Üniversitesi Sosyal Bilimler Enstitüsü Dergisi, 5(9), 7-22

Üstün, E. (2011) Öğretmen adaylarının kültürlererası duyarlıllk ve etnikmerkezcilik düzeylerini etkileyen etmenler. [Factors affecting teacher candidates' intercultural sensitivity and ethnocentrism levels] (Yayımlanmamış yüksek lisans tezi) [Unpublished master's thesis]. Yıldız Teknik Üniversitesi Sosyal Bilimler Enstitüsü, İstanbul.

Yücel, N. (2016). Toward Intercultural Teacher Education: A Case Study of Pre-service English Language Teachers (Unpublished doctoral dissertation). Çanakkale Onsekiz Mart Üniversitesi Eğitim Bilimleri Enstitüsü, Çanakkale.

The Higher Education Council $\square$ Yüksek Öğretim Kurumu $\square$ (2011). Türkiye yükseköğretim yeterlilikler çerçevesi (TYYÇ) temel alan yeterlilikleri. Retrieved from http://tyyc.yok.gov.tr/?pid=48 